\title{
HUBUNGAN ANTARA KADAR ASAM URAT DENGAN TEKANAN DARAH PADA MAHASISWA PRIA OBESITAS SENTRAL FAKULTAS KEDOKTERAN UNIVERSITAS SAM RATULANGI MANADO
}

\author{
${ }^{1}$ Siti N. Mansur \\ ${ }^{2}$ Frans E. Wantania \\ ${ }^{2}$ Eko Surachmanto
}

\author{
${ }^{1}$ Kandidat Skripsi Fakultas Kedokteran, Universitas Sam Ratulangi Manado \\ ${ }^{2}$ Bagian Ilmu Penyakit Dalam BLU RSU Prof. Dr. R. D. Kandou Manado \\ Email: nurzeyla@yahoo.com
}

\begin{abstract}
Inflammation plays an important role in hypertension process and central obesity. Recent studies found that hyperuricemia was also related to inflammation. This study aimed to find out the relation between uric acid level with blood pressure among central-obese-male students in the Faculty of Medicine Unsrat. Methods: This was an analytical study with a cross section design. There were 37 people as samples. Data were obtained by measuring the waist size, blood pressure, and uric acid. The data were analyzed with the Statistical Product and Service Solution (SPSS) and Pearson correlation test. The results showed that most respondents were 19 years old (12 respondents, 32.4\%) and the lowest were 17, 22 and 23 years old, each of them was 1 person (2.7\%). The mean systolic blood pressure was 130.54 $\mathrm{mmHg}(\mathrm{SD} \pm 10.259)$. The mean diastolic blood pressure was $88.11 \mathrm{mmHg}(\mathrm{SD} \pm 7.760)$. The mean level of uric acid was $7.514 \mathrm{mg} / \mathrm{dL}$ ( $\mathrm{SD} \pm 1.65$ ). This study showed that there was some significant relation between the systolic blood pressure and uric acid level $(\mathrm{p}=0.019)$, as well as between the diastolic blood pressure and uric acid level $(p=0.022)$. Conclusion: There was a significant correlation between the uric acid level and blood pressure in male students with central obesity.
\end{abstract}

Keywords: obesity, uric acid, blood pressure

\begin{abstract}
Abstrak: Inflamasi berperan penting dalam proses terjadinya hipertensi dan obesitas sentral. Pada penelitian terkini ditemukan bahwa hiperurisemia juga berhubungan dengan proses inflamasi. Penelitian ini bertujuan untuk mengetahui hubungan antara kadar asam urat dengan tekanan darah pada mahasiswa pria obesitas sentral Fakultas Kedokteran Unsrat. Penelitian ini bersifat analitik menggunakan rancangan potong lintang dengan sampel berjumlah 37 orang. Data diperoleh melalui pemeriksaan lingkar perut, tekanan darah, dan asam urat. Data dianalisis dengan menggunakan Statistical Product and Service Solution (SPSS) dan uji Pearson correlation. Hasil penelitian memperlihatkan bahwa sebagian besar responden berada pada kategori umur 19 tahun (12 responden, 32,4\%) dan terendah umur 17, 22, dan 23 tahun masing-masing sejumlah 1 orang (2,7\%). Berdasarkan nilai mean dapat dilihat bahwa rerata tekanan darah sistol 130,54 mmHg (SD \pm 10,259). Rerata tekanan darah diastol 88,11 $\mathrm{mmHg}$ (SD $\pm 7,760$ ). Rerata kadar asam urat responden 7,514 mg/dL (SD $\pm 1,65)$. Hasil penelitian menunjukkan secara statistik terdapat hubungan yang bermakna, baik antara tekanan darah sistol dan asam urat $(\mathrm{p}=0,019)$ maupun antara tekanan darah diastol dan kadar asam urat $(\mathrm{p}=0,022)$. Simpulan: Terdapat hubungan bermakna antara kadar asam urat dan tekanan darah pada mahasiswa pria obesitas sentral.
\end{abstract}

Kata kunci: obesitas, asam urat, tekanan darah 
Obesitas sentral adalah kegemukan yang didominasi penumpukan lemak di bagian abdomen (viseral). Obesitas sentral (obesitas viseral) akan disertai dengan peningkatan risiko berbagai penyakit kronis, termasuk penyakit arteri koroner, diabetes, hipertensi, stroke, dan jenis-jenis kanker tertentu. ${ }^{1}$ Obesitas disebabkan oleh pemasukan jumlah makanan yang lebih besar daripada pemakaiannya oleh tubuh sebagai energi. ${ }^{2}$ Obesitas telah mencapai proporsi epidemi global, dengan sedikitnya 2,8 juta orang meninggal setiap tahun sebagai kelebihan berat badan atau obesitas. $^{3}$

Hiperurisemia adalah keadaan dimana terjadi peningkatan kadar asam urat serum diatas normal. ${ }^{4,5,6}$ Kadar asam urat $>7$ $\mathrm{mg} / \mathrm{dl}$ pada laki-laki dan $>6 \mathrm{mg} / \mathrm{dl}$ pada perempuan dipergunakan sebagai batasan hiperurisemia $^{4}$ Menurut penelitian didapatkan prevalensi tertinggi terdapat di Manado-Minahasa. Hal ini disebabkan karena kebiasaan mengkonsumsi daging dan alkohol yang merupakan bahan makanan yang tinggi kadar purinnya. ${ }^{7} \mathrm{Di}$ Minahasa, prevalensi hiperurisemia pada laki-laki dewasa muda adalah sebesar $34,40 \%$ dan wanita $23,31 \%{ }^{8}$

Beberapa studi juga menunjukan hubungan antara asam urat dengan hipertensi, obesitas, penyakit ginjal dan penyakit kardiovaskuler. Lebih dari 70\% penderita dengan hiperurisemia mengalami obesitas, lebih dari 50\% dengan hipertensi, $10-25 \%$ meninggal akibat penyakit ginjal. ${ }^{9}$ Terdapat kesamaan antara orang yang mengalami hiperurisemia dan yang obesitas yaitu pola makan yang tidak terkontrol. Dari penelitian di sebutkan bahwa faktorfaktor yang berhubungan dengan kejadian hiperurisemia adalah jenis kelamin, IMT, asupan karbohidrat dan asupan purin. ${ }^{10}$

Kegemukan meningkatkan risiko hipertensi, diabetes melitus, dan aterosklerosis. $^{11}$ Obesitas adalah faktor risiko yang sangat menentukan tingkat keparahan hipertensi. Semakin besar massa tubuh seseorang, semakin banyak darah yang dibutuhkan untuk menyuplai oksigen dan nutrisi ke otot dan jaringan. ${ }^{12}$ Obesitas memberikan hasil pada kondisi proinflammatori mulai dari sel metabolik (adiposit, hepatosit atau miosit) dan juga merekrut sel imun dengan pelepasan konsekuen dari inflamatori sitokinin (TNFalpha, IL-6, adiponektin, dll). Telah dihipotesiskan bahwa proses inflamatori yang dipengaruhi oleh obesitas mungkin mengarah pada komplikasi seperti hipertensi, aterosklerosis, dyslipidemia, ketahanan insulin dan diabetes mellitus. ${ }^{13}$

Penelitian sebelumnya terdapat hubungan antara asam urat dengan hipertensi tetapi hanya bermakna pada dewasa. Berdasarkan latar belakang diatas serta penelitian sebelumnya maka penulis mempunyai keinginan untuk mengetahui apakah terdapat hubungan antara kadar asam urat dengan tekanan darah pada dewasa muda atau remaja khususnya mahasiswa obesitas sentral Fakultas Kedokteran Universitas Sam Ratulangi.

\section{METODE PENELITIAN}

Jenis penelitian yang dilakukan bersifat analitik dengan pendekatan cross sectional. Penelitian dilaksanakan pada bulan September-Desember 2014. Populasi penelitian adalah seluruh mahasiswa di Fakultas Kedokteran Universitas Sam Ratulangi. Subyek penelitian adalah mahasiswa obese di Fakultas Kedokteran Universitas Sam Ratulangi. Kriteria inklusi meliputi mahasiswa fakultas kedokteran unsrat, lingkar pinggang $>90 \mathrm{~cm}$, usia 1825 tahun, dan bersedia ikut dalam penelitian dengan menandatangani (informed consent). Kriteria ekslusi meliputi sedang dalam program diet, sedang sakit, seorang atlet, sedang dalam penggunaan obat yang mempengaruhi kadar asam urat dan tekanan darah. Sampel penelitian berjumlah 37 orang. Variabel yang digunakan untuk variabel bebas kadar asam urat variabel tergantung tekanan darah. Analisis data adalah analisis univariat dan bivariat dengan menggunakan uji statistik korelasi dengan bantuan komputer program SPSS versi 21. 


\section{HASIL PENELITIAN}

Hasil penelitian tentang hubungan tekanan darah sistol dan diastol dengan kejadian asam urat disajikan dalam bentuk analisis univariat yang mencakup tentang karakteristik umur, tekanan darah sistol, tekanan darah diastol, asam urat, nilai mean, standar deviasi, nilai minimum dan maksimum masing-masing variabel penelitian pada 37 responden yang terpilih, sedangkan analisis bivariat mencakup hasil deskriptif tabulasi silang tekanan darah sistol dengan asam urat, tekanan darah diastol dengan asam urat, hubungan tekanan darah sistol dengan asam urat dan hubungan tekanan darah diastol dengan asam urat.

\section{Analisis Univariat}

Berdasarkan Tabel 1 dan Gambar 1 dapat dilihat bahwa sebagian besar responden yang dijadikan sampel penelitian berada pada kategori umur 19 tahun yang berjumlah 12 responden (32,4\%), umur 18 tahun berjumlah 10 responden (27\%), umur 20 tahun berjumlah 9 responden $(24, \%)$, umur 21 tahun berjumlah 3 orang $(8,1 \%)$ dan umur 17, 22, dan 23 tahun masingmasing berjumlah 1 orang (2,7\%).

Tabel 1. Distribusi Frekuensi Berdasarkan Umur

\begin{tabular}{ccc}
\hline Umur & $\mathbf{n}$ & $\mathbf{\%}$ \\
\hline 17 tahun & 1 & 2,8 \\
18 tahun & 10 & 27 \\
19 tahun & 12 & 32,3 \\
20 tahun & 9 & 24,2 \\
21 tahun & 3 & 8,1 \\
22 tahun & 1 & 2,8 \\
23 tahun & 1 & 2,8 \\
\hline Total & 37 & 100 \\
\hline
\end{tabular}

Berdasarkan Tabel 2 dan Gambar 2 dapat dilihat bahwa sebagian besar responden yang dijadikan sampel penelitian mempunyai ukuran tekanan darah sistol dengan kategori normal dengan jumlah 28 responden $(75,7 \%)$ dan yang tidak normal berjumlah 9 responden (22,5\%).

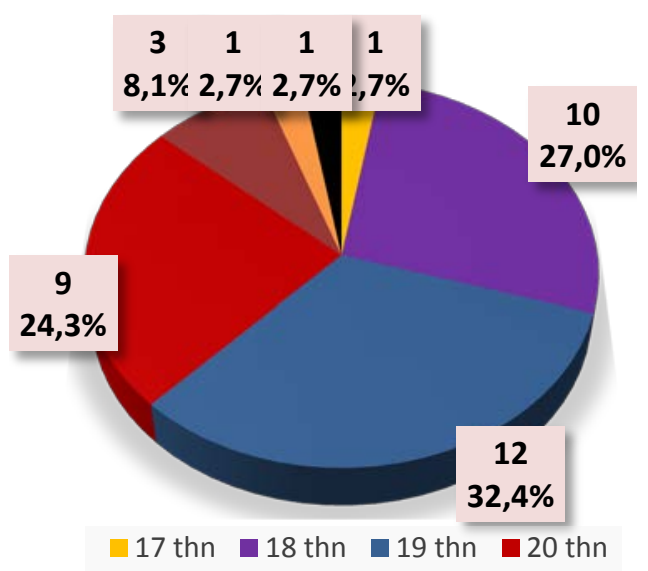

Gambar 1. Grafik Berdasarkan Kategori Umur Responden

Tabel 2. Distribusi Frekuensi Berdasarkan Tekanan Darah Sistol

\begin{tabular}{lcc}
\hline $\begin{array}{l}\text { Tekanan } \\
\text { Darah Sistol }\end{array}$ & n & \% \\
\hline Normal & 28 & 75,7 \\
Tidak Normal & 9 & 22,5 \\
\hline Total & 40 & 100 \\
\hline
\end{tabular}

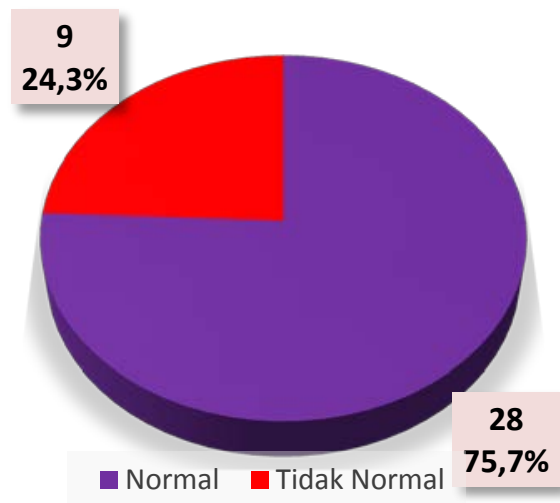

Gambar 2. Grafik Berdasarkan Kategori Tekanan Darah Sistol

Berdasarkan Tabel 3 dapat dilihat bahwa sebagian besar responden yang dijadikan sampel penelitian mempunyai ukuran tekanan darah dengan ketegori tidak normal dengan jumlah 24 responden (65\%) dan yang normal berjumlah 13 responden (35\%). 
Tabel 3. Distribusi Frekuensi Berdasarkan Tekanan Darah Diastol

\begin{tabular}{ccc}
\hline $\begin{array}{c}\text { Tekanan darah } \\
\text { diastol }\end{array}$ & n & \% \\
\hline Normal & 13 & 35 \\
Tidak normal & 24 & 65 \\
\hline Total & 37 & 100 \\
\hline
\end{tabular}

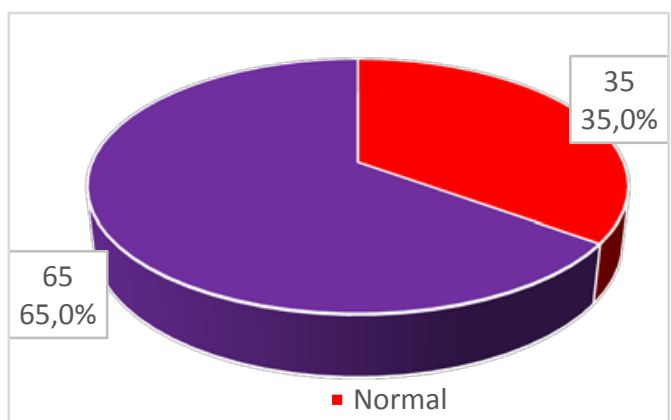

Gambar 3. Grafik Berdasarkan Kategori Tekanan Darah Diastol

Berdasarkan Tabel 4 dan Gambar 4 dapat dilihat bahwa sebagian besar responden yang dijadikan sampel penelitian mempunyai kadar asam dengan kategori normal dengan jumlah 15 responden
(40,5\%) dan yang tidak normal berjumlah 22 responden $(59,5 \%)$.

\section{Tabel 4. Distribusi Frekuensi Berdasarkan Kadar Asam Urat}

\begin{tabular}{ccc}
\hline Kadar Asam Urat & $\mathbf{N}$ & $\mathbf{\%}$ \\
\hline Normal & 15 & 40,5 \\
Tidak Normal & 22 & 59,5 \\
\hline Total & 37 & 100 \\
\hline
\end{tabular}

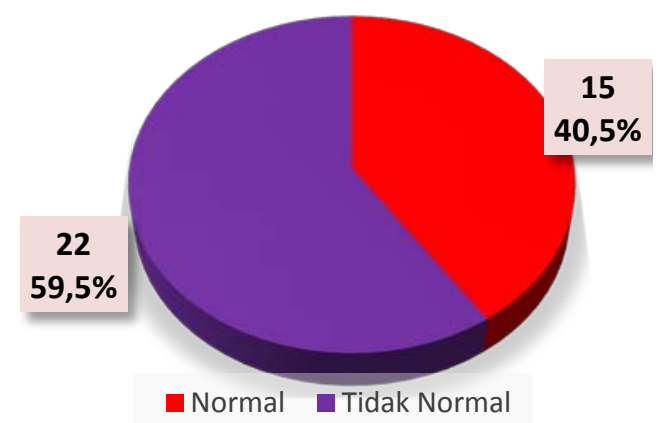

Gambar 4. Grafik Berdasarkan Kategori Kadar Asam Urat

Tabel 5. Nilai Mean, SD, Minimum dan Maksimum

\begin{tabular}{ccccc}
\hline & Mean & SD & Minimum & Maksimum \\
& & & & \\
\hline TD Sistol & 130,54 & 10,259 & 120 & 170 \\
TD Diastol & 88,11 & 7,760 & 80 & 110 \\
Asam Urat & 7,514 & 1,65 & 3,8 & 12,4 \\
\hline
\end{tabular}

Berdasarkan Tabel 5 dapat dilihat bahwa rerata variabel tekanan darah sistol responden 130,54 mmHg, nilai SD 10,259, nilai minimum $120 \mathrm{mmHg}$, dan nilai maksimum $170 \mathrm{mmHg}$. Rerata variabel tekanan darah diastol responden 88,11 mmHg, nilai SD adalah 7,760, nilai minimum $80 \mathrm{mmHg}$, dan nilai maksimum $110 \mathrm{mmHg}$. Rerata variabel kadar asam urat responden 7,514 mg/dL, nilai SD 1,65, nilai minimum $3,8 \mathrm{mg} / \mathrm{dL}$, dan nilai maksimum 12,4 mg/dL.

Tabel 6 menggambarkan bahwa dari
37 responden penelitian sebagian besar responden yang mempunyai tekanan darah sistol kategori normal mempunyai kadar asam urat yang tidak normal sebanyak 16 responden (43,2\%), sedangkan yang dengan kadar asam urat normal sebanyak 12 responden (32,4\%). Responden yang mempunyai tekanan darah sistol dengan kategori tidak normal mempunyai kadar asam urat yang tidak normal sebanyak 6 responden (16,2\%), sedangkan dengan kadar asam urat yang normal sebanyak 3 responden (8\%). 
Jurnal e-Clinic (eCl), Volume 3, Nomor 1, Januari-April 2015

\section{Analisis Bivariat}

Hasil Deskriptif TD Sistol Berdasarkan Kadar Asam Urat

Tabel 6. Hasil Tabulasi Silang TD Sistol Berdasarkan Kadar Asam Urat

\begin{tabular}{|c|c|c|c|c|c|c|c|}
\hline & & \multicolumn{4}{|c|}{ Asam Urat } & \multirow{2}{*}{\multicolumn{2}{|c|}{ Total }} \\
\hline & & \multicolumn{2}{|c|}{ Normal } & \multicolumn{2}{|c|}{ Tidak Normal } & & \\
\hline & & $\mathrm{n}$ & $\%$ & $\mathrm{~N}$ & $\%$ & $\mathrm{n}$ & $\%$ \\
\hline \multirow{2}{*}{$\begin{array}{c}\text { TD } \\
\text { Sistol }\end{array}$} & Normal & 12 & 32,4 & 16 & 43,2 & 28 & 75,7 \\
\hline & $\begin{array}{c}\text { Tidak } \\
\text { Normal }\end{array}$ & 3 & 8 & 6 & 16,2 & 9 & 24,3 \\
\hline & tal & 15 & 40,5 & 22 & 59,4 & 37 & 100 \\
\hline
\end{tabular}

\section{Hasil Deskriptif TD Diastol Berdasarkan Kadar Asam Urat}

Tabel 7. Hasil Tabulasi Silang TD Diastol Berdasarkan Kadar Asam Urat

\begin{tabular}{|c|c|c|c|c|c|c|c|}
\hline & & \multicolumn{4}{|c|}{ Asam Urat } & \multirow{2}{*}{\multicolumn{2}{|c|}{ Total }} \\
\hline & & \multicolumn{2}{|c|}{ Normal } & \multicolumn{2}{|c|}{ Tidak Normal } & & \\
\hline & & $\mathrm{N}$ & $\%$ & $\mathrm{~N}$ & $\%$ & $\mathrm{~N}$ & $\%$ \\
\hline \multirow{3}{*}{$\begin{array}{c}\text { TD } \\
\text { Diastol }\end{array}$} & Normal & 7 & 18,9 & 8 & 21,6 & 15 & 40,6 \\
\hline & Tidak Normal & 7 & 18,9 & 15 & 40,6 & 22 & 59,4 \\
\hline & Total & 14 & 37,8 & 23 & 62,2 & 37 & 100 \\
\hline
\end{tabular}

Tabel 7 menggambarkan bahwa dari 40 responden penelitian sebagian besar responden yang mempunyai tekanan darah diastol dengan kategori normal mempunyai kadar asam urat yang tidak normal sebanyak 8 responden (21,6\%), sedangkan dengan kadar asam urat yang normal sebanyak 7 responden (18,9\%). Responden yang mempunyai tekanan darah diastol dengan kategori tidak normal mempunyai kadar asam urat yang tidak normal sebanyak 15 responden (40,6\%), sedangkan dengan kadar asam urat yang normal sebanyak 7 responden (18,9\%).

Tabel 8 menjelaskan bahwa hasil uji statistik dengan menggunakan Pearson Correlation didapatkan hasil pemeriksaan tekanan darah sistol mempunyai hubungan yang signifikan dengan kadar asam urat pada mahasiswa pria obesitas sentral $(p=0,019)$

\section{Hubungan Tekanan Darah Sistol dengan} Kadar Asam Urat

Tabel 8. Hubungan Tekanan Darah Sistol dengan Kadar Asam Urat

\begin{tabular}{ccc}
\hline Variabel & $\mathbf{r}$ & $\mathbf{p}$ \\
\hline $\begin{array}{c}\text { Tekanan Darah Sistol } \\
\text { - Asam Urat }\end{array}$ & $0,383^{*}$ & 0,019 \\
\hline
\end{tabular}

\section{Hubungan Tekanan Darah Diastol dengan Kadar Asam Urat}

Tabel 9. Hubungan Tekanan Darah Diastol dengan Kadar Asam Urat

\begin{tabular}{ccc}
\hline Variabel & $\mathbf{r}$ & $\mathbf{p}$ \\
\hline $\begin{array}{c}\text { Tekanan Darah } \\
\text { Diastol - Asam } \\
\text { Urat }\end{array}$ & $0,375^{*}$ & 0,022 \\
& & \\
\hline
\end{tabular}


Berdasarkan Tabel 9 menjelaskan bahwa hasil uji statistik dengan menggunakan Pearson Correlation didapatkan hasil pemeriksaan tekanan darah diastol mempunyai hubungan yang signifikan dengan kadar asam urat pada mahasiswa pria obesitas sentral $(\mathrm{p}=0,022)$.

\section{BAHASAN}

Dari hasil penelitian ini berdasarkan umur paling muda adalah 17 tahun dan umur yang paling tua adalah 23 tahun, dimana sebagian besar responden yang dijadikan sampel penelitian berada pada kategori umur 19 tahun yang berjumlah 12 responden (32,4\%). Hasil ini sesuai dengan penelitian yang dilakukan oleh Rotty L dimana di Minahasa, prevalensi hiperurisemia pada laki-laki dewasa muda adalah sebesar $34,40 \%$ dan wanita 23,31\%. ${ }^{7}$

Dari hasil penelitian ini berdasarkan kadar asam urat yang didapatkan pada mahasiswa pria obesitas dengan kategori kadar asam urat yang tidak normal berjumlah 22 responden (59,5\%). Hal ini dapat menjelaskan hiperurisemia pada obesitas terjadi melalui resistensi hormon insulin. Pada tubuh yang akan mengalami obesitas akan terjadi peningkatan pelepasan jumlah asam lemak bebas ke dalam sirkulasi. Masuknya asam lemak bebas yang berlebihan ini ke dalam otot mengakibatkan terjadinya resistensi insulin. Resistensi insulin, hipoksia, dan kematian sel dapat menginduksi perubahan xanthine dengan bantuan air dan oksigen akan berubah menjadi asam urat yang menghasilkan peroksida. Insulin juga berperan dalam meningkatkan reabsorbsi asam urat di tubuli proksimal ginjal. Sehingga pada keadaan hiperinsulinemia pada pra diabetes terjadi peningkatan reabsorbsi yang akan menyebabkan hiperurisemia. ${ }^{15,16}$

Studi oleh Pasifico EL et al tahun 2009 pada anak dan remaja menemukan bahwa hiperurisemia berhubungan erat dengan obesitas, lebih khusunya penderita sindroma metabolik. Selain itu, hiperurisemia berhubungan erat dengan jenis kelamin laki-laki dan pertambahan usia. $^{18}$

Hiperurisemia sering didapatkan pada pasien hipertensi. Dalam penelitian ini sebagian besar responden memiliki tekanan darah sistol dengan kategori normal, dimana memiliki jumlah 28 responden $(75,7 \%)$. Sedangkan responden dengan tekanan darah diastol memiliki jumlah lebih besar pada kategori tidak normal dengan jumlah 24 responden (65\%).

Secara teori menjelaskan hubungan hiperurisemia dengan hipertensi, hipertensi akan berakhir dalam penyakit mikrovaskuler dengan hasil akhirnya berupa iskemi jaringan yang akan meningkatkan sintesis asam urat melalui degradasi ATP menjadi adenin dan xantin. Peneliti lain menyimpulkan bahwa peningkatan tekanan darah akan menyebabkan iskemi. Hiperurisemia yang berlangsung lama dapat menyebabkan penyakit ginjal kronis dangan perubahan tubuler. Pada hewan percobaan dengan hiperurisemia ringan, hipertensi terjadi setelah beberapa minggu. ${ }^{14}$

Berdasarkan hasil analisis menggunakan uji Pearson terdapat hubungan yang signifikan, baik antara variabel tekanan darah sistol dengan kadar asam urat $(p=0,019)$ maupun antara variabel tekanan darah diastol dengan kadar asam urat $(p=0,022)$. Hal ini sangat sesuai dengan penelitian sebelumnya yang menyatakan bahwa terdapat hubungan antara asam urat dengan hipertensi tetapi hanya bermakna pada dewasa.

Dengan demikian hipotesis $\mathrm{H}_{1}$ yang menyatakan bahwa terdapat hubungan antara kadar asam urat dengan tekanan darah pada mahasiswa pria obesitas sentral terbukti kebenarannya secara statistik.

\section{DAFTAR PUSTAKA}

1. Hartono A. Terapi gizi dan diet rumah sakit. Jakarta: penerbit buku kedokteran EGC. 2006: 173

2. Guyton AC, Hall JE. 2007. Buku Ajar Fisiologi Kedokteran edisi 11.EGC. Jakarta. 2007. p. 902-906,1070

3. World Health Organization. 10 fact on 
obesity. Switzerland. 2012. Available

from:

URL:

http://www.who.int/features/factfiles/

obesity/en

4. Putra TR. Hiperurisemia. Dalam: Sudoyo WA, Sutiyohadi B, Alwi I, Simandibrata K.M, Setiati S, editor. Buku Ajar Ilmu Penyakit Dalam. Jilid III. Ed 5, Jakarta EGC; 2009. p. 25502555

5. Wortmann RL, Schumacher HR, Chen LX. Hyperuricemia and Gout. Dalam: Jameson JL, Loscaso J, editor. Harrison's Nephrology and Acid Base Disorders. The McGraw-Hill Companies. US; 2010. p. 78-84

6. Burn DK, Kumar V, Sistem Muskuloskeletal. Dalam: Hartanto H, Darmaniah N, Wulandari N, editor. Buku ajar Patologi Robbins. Ed 7.

Vol 2. Jakarta EGC; 2007. p. 864-865

7. Rotty L. Gambaran Asam Urat Pada Suku Minahasa Usia Dewasa Muda. Bagian Ilmu Penyakit Dalam. Manado: Fakultas Kedokteran Universitas Sam Ratulangi. Thesis; 1999

8. Harison. Prinsip-Prinsip Ilmu Penyakit Dalam.Edisi ke-13. EGC. hal: 498

9. Kowalski E Robert. Terapi Hipertensi Program 8 Minggu. Qonita, 2010. p. 41

10.Pacifico L, Cantisani V, Anania C, Bonaiuto E, Martino F, Pascone R, et al. Serum uric acid and its association with metabolic syndrome and carotid atherosclerosis in obese children. Eur J Endocrinol, 2009; 160: 45-52.

11.Wantania F, Lefrandt L.R, Pandelaki K. Adiponectin and tumor necrosis factor alfa levels, and their correlations with endothelial dysfunction in central obesity. Jurnal biomedik. 2011. Vol 3, No-3, 179185.

12.Karimba A, Kaligis S, Purwanto D. Gambaran Kadar Asam Urat Pada
Mahasiswa Angkatan 2011 Fakultas

Kedokteran Universitas Sam

Ratulangi dengan IMT $>23 \mathrm{~kg} / \mathrm{m}^{2}$. Jurnal e-biomedik; Vol 1. Maret 2013.

13.Nasrul E, Sofitri. Hiperurisemia pada Pra Diabetes. Jurnal kesehatan Andalas 2012. Di akses dari : http://www.jurnal.fk.unand.ac.id/artic les/vol_1no_2/86-91.pdf. h.86-91. Tanggal 8 desember 2014.

14.Tjokorda Raka Putra. Hiperurisemia. Dalam Buku Ajar Ilmu Penyakit Dalam Jilid III. Edisi ke-5. Jakarta: Pusat Penerbitan Ilmu Penyakit Dalam, p: 2551-54

15.Kumar, S. Prevalence of hyperuricemia in Chitwan District of Nepal. Journal of college of Medical Science-Nepal. 2010. Vol 6, No-2, 18-23

16. Chobanian AV, Bakris GL, Black HR, Cushman WC, Green LA. et al.

The Seventh Report o High Blood

Pressure: The JNC 7 Report.Hypertension 2003; 42: 120652

17. Riset Kesehatan Dasar 2013

18.Sugondo sudartawan. Obesitas. Dalam sudoyo, A.W,Sutiyohadi B, Alwi I, Simandibrata K.M,Setiati S. Buku ajar Ilmu Penyakit Dalam jilid III, edisi V. Jakarta: pusat penerbitan department Ilmu Penyakit Dalam FK UI. november 2009: 1973-83

19. Chobanian AV, Bakris GL, Black HR, Cushman WC, Green LA. et al. The Seventh Report o High Blood Pressure: The JNC 7 Report.Hypertension 2003; 42: 120652.

20.Rosita E. Profil Hipertensi dengan Obesitas pada pasien di poliklinik ginjal dan hipertensi (skripsi). Manado: FKUNSRAT: 2012. p. 6

21.Davey Patrick At A Glance Medicine. EMS, 2003. p. 138. 